\author{
Halina Kurek \\ Uniwersytet Jagielloński \\ Wydział Polonistyki \\ ORCID 0000-0002-9578-7293; e-mail: halina.kurek@uj.edu.pl
}

\title{
Zanikanie formantów rodzinnych w gwarach a nietypowe problemy badawcze współczesnej dialektologii (na przykładzie wsi poddukielskich w Beskidzie Niskim)
}

\begin{abstract}
Abstrakt: Przedmiotem artykułu są nietypowe problemy badawcze, na które od przełomu wieków XX i XXI natrafiają współcześni badacze języka mówionego wsi. W opisie przemian językowych społeczności wiejskich muszą oni bowiem uwzględniać zarówno przeobrażenia dokonujące się w gwarach, jak i w języku ogólnopolskim, ponieważ przedmiotem ich analiz staje się substandard wiejski, dodatkowo nieustannie modyfikowany przez polszczyznę medialną i wzorce angloamerykańskie. Nietypowe problemy badawcze pokazuję na przykładzie zanikających „,formantów rodzinnych”, czyli przyrostków służących w gwarach do tworzenia nazw żon, synów i córek, zebranych we wsiach poddukielskich w Beskidzie Niskim. Materiał obejmujący cały wiek XX i początek wieku XXI zawiera też przykłady wskazujące na zjawisko odfleksyjniania imion i nazwisk w substandardzie wiejskim w strukturach składniowych typu: imię + od + gen. sg. nazwiska // imienia // przezwiska ojca lub matki.
\end{abstract}

Słowa kluczowe: zmiany językowe, formanty rodzinne w gwarach, nietypowe problemy badawcze.

\begin{abstract}
Disappearance of family formants in local dialects vs. non-typical research issues in contemporary dialectology (based on the example of villages located near Dukla in the Low Beskids. The subject of the article includes non-typical research issues faced by contemporary researchers of the language spoken in the village since the late $20^{\text {th }}$ and the early $21^{\text {st }}$ century. In the description of the linguistic changes of the village communities, the researchers need to take into account the changes taking place both in dialects and in the general Polish language. This is because the subject of their analyses includes the rural sub-standard which is also constantly modified by the media Polish and the English-language standards. I have shown non-typical research problems based on the examples of disappearing "family formants", i. e. suffixes which, in local dialects, are used to create the names of wives, sons and daughters. These formants have been collected in villages near Dukla in the Low Beskids. The material, which encompasses the entire $20^{\text {th }}$ century and the early $21^{\text {st }}$ century, also contains some examples showing the phenomenon of removing the inflection of first names and surnames in the rural sub-standard in the syntactic structures like first name $+o d+$ gen. sg. surname // first name // nickname of father or mother.
\end{abstract}

Keywords: linguistic changes, family formants in local dialects, non-typical research problems.

\section{Przemiany społeczno-ekonomiczne powojennej wsi a zmiany językowe}

Po 1945 roku polska wieś znalazła się w nowej rzeczywistości politycznej, która na tych obszarach wywołała poważne zmiany gospodarczo-ekonomiczne, demograficzne, 
społeczne i etniczno-kulturowe. Migracja do miast doprowadziła do deformacji struktury społeczno-demograficznej wsi: odchodzenia od zajęć w rolnictwie, co skutkowało powstaniem bardzo licznej grupy ludności dwuzawodowej - chłopów-robotników oraz jednozawodowej - robotników, spadku i tak bardzo niskiego poziomu wykształcenia społeczności wiejskich oraz tzw. starzenia się wsi (Kurek 2019b, 25-26).

Z drugiej strony, rozbudowa przemysłu i upowszechnienie szkolnictwa poprzez wprowadzenie obowiązku ukończenia szkoły podstawowej oraz zniesienie opłat za naukę umożliwiające młodzieży, zwłaszcza ze środowisk robotniczych i chłopskich, szeroki dostęp do szkół, wpływ prasy, a także środków masowego przekazu: radia i telewizji, spowodowały natomiast na wsi nasilenie się kontaktów z polszczyzną potoczną oraz z mówionym i zapisanym językiem ogólnopolskim.

Kolejne zmiany polityczne i początek rzeczywistej transformacji gospodarczej, społeczno-ekonomicznej i kulturowej obszarów wiejskich przyniósł rok 1989, a przyjęcie Polski do Unii Europejskiej 1 maja 2004 roku spowodowało, że przekształceniami strukturalnymi polskiej wsi zajęła się również Komisja Europejska. Po roku 1989 „W ciągu życia jednego pokolenia radykalnie zmieniły się [więc - uzup. H.K.] relacje ekonomiczne i kulturowe [...] wsi, a nasze rolnictwo przeżyło niebywały skok jakościowy od tradycyjnych metod uprawy roli i hodowli do nowoczesnych technologii produkcji roślinnej i zwierzęcej - technologii już przemysłowych" (Ożóg 2007, 214).

W okresie transformacji ustrojowej na obszarach wiejskich zanotowano nie tylko spowolnienie procesu migracji do miast, lecz także tendencję przeciwną, tzn. przeprowadzanie się na wieś mieszkańców pobliskich aglomeracji miejskich. Jest to związane z szybkim zacieraniem się różnic cywilizacyjnych pomiędzy wsią i miastem, zwłaszcza dzięki powszechnemu dostępowi do mediów elektronicznych: komputera, telefonu komórkowego oraz telewizji satelitarnej i kablowej. Nowe technologie, umożliwiając wspólnotom wiejskim szybki dostęp do informacji i niemal nieograniczone możliwości komunikacyjne, jednocześnie wprowadziły polską wieś w obręb globalnej kultury technomenedżerskiej w stylu amerykańskim (Kurek 2018, 85-86).

Zmiany ustrojowe i społeczno-ekonomiczne zachodzące na obszarach wiejskich nie pozostały bez wpływu na język ich mieszkańców. Dominująca do połowy XX wieku gwara po wojnie zaczęła ustępować prestiżowej polszczyźnie ogólnej. W nowej rzeczywistości znaczenie i siła dialektów okazały się bowiem mniejsze niż język normalizowany, „który cieszy się większym prestiżem, gdyż prestiż ten tworzy i podtrzymuje literatura piękna, naukowa i popularnonaukowa, całe piśmiennictwo, instytucje naukowe i kulturalne [...] kraju" (Miodunka 2003, 13). W pierwszej fazie omawianego procesu gwarę usuwano z komunikacji oficjalnej, w drugiej - z kontaktów językowych o charakterze nieformalnym. Zawsze jednak przeobrażenia wiejskiego systemu językowo-kulturowego rozpoczynały się w pokoleniu najmłodszym. W rezultacie, w drugiej połowie XX wieku społeczność wiejska stopniowo stawała się bilingwalna, i był to bilingwizm typu dialekt : substandard wiejski (Kurek 2019b, 29-30).

Na przełomie XX i XXI wieku ,językiem codziennej komunikacji” (Handke 2008, 272-273) najmłodszego pokolenia mieszkańców wsi była już wyłącznie polszczyzna substandardowa typu wiejskiego (Kurek 2019, 31), od lat dziewięćdziesiątych XX wieku nieustannie modyfikowana przez polski język medialny i, na skutek procesów globalizacyjnych, przez amerykańskie wzorce językowo-kulturowe (Ożóg 2007, 217-218). 
Od około trzydziestu lat substandard wiejski pełni więc na wsi funkcję bazy służącej do „kształtowania nowego wzorca językowego, odległego od kanonów kulturalnej polszczyzny drugiej połowy XX w." (Markowski 2005, 144), a także od macierzystych gwar.

Od przełomu wieków XX i XXI dialektolodzy natrafiają zatem na wsi na nietypowe problemy badawcze, ponieważ w opisie przemian językowych społeczności wiejskich muszą uwzględniać zarówno przeobrażenia dokonujące się w gwarach, jak i w języku ogólnopolskim. Przedmiotem ich analiz staje się bowiem substandard wiejski, dodatkowo nieustannie modyfikowany przez polszczyznę medialną i wzorce angloamerykańskie.

\section{Zanikanie formantów rodzinnych w polszczyźnie ogólnej i w gwarach}

Powojenne zmiany językowe wiejskiego obszaru kulturowego objęły wszystkie płaszczyzny systemu dialektalnego, w tym również słowotwórstwo. $Z$ tego zakresu jednym z ważniejszych problemów badawczych podejmowanych często przez opracowania naukowe jest zanikanie tzw. formantów rodzinnych, czyli przyrostków służących do tworzenia nazw żon, córek i synów od nazwisk (imion, przezwisk) mężów i ojców. Ich zasób zarówno w polszczyźnie ogólnej, jak i w gwarach ludowych, jest bowiem od wieków nieustannie ograniczany i modyfikowany (Karaś 2017, 156).

W języku ogólnopolskim najwcześniej, bo już w XVIII wieku, zaprzestano używać formantów patronimicznych oznaczających synów (-ic/z/, -owic/z/) (Kosyl 1993, 434). Przyrostki tworzące formy odmężowskie i odojcowskie określenia córek (-owa, -ina/ -yna, -ówna, -anka) w ogólnej odmianie polszczyzny mówionej zachowały się, co prawda, do dziś, jednak już w postaci szczątkowej (Karaś 2017, 155-156).

W gwarach ludowych nawet w okresie powojennym zakres użycia formantów rodzinnych był jeszcze stosunkowo szeroki. Mieczysław Karaś w artykule zatytułowanym $O$ gwarowych formantach onomastycznych, wydanym po raz pierwszy w 1968 roku, pisał, że w systemie słowotwórczym

do ważniejszych różnic między językiem literackim a gwarami ludowymi trzeba zaliczyć zróżnicowanie morfologiczne z zakresu nazw żon, synów i córek [...] W porównaniu z językiem literackim dialekty ludowe reprezentują [bowiem - uzup. H.K.] stan znacznie bardziej pierwotny i od strony morfologicznej o wiele bogatszy. [...] I co ciekawsze, w ostatnim okresie jesteśmy niemal świadkami pogłębiania się różnic (Karaś 2017, 157).

\section{Zanikanie formantów rodzinnych w gwarach poddukielskich}

W niniejszym artykule zanikanie formantów rodzinnych w dialektach pokazuję na materiale zaczerpniętym z gwar poddukielskich (Beskid Niski), obejmującym cały wiek XX i niemal pierwszą ćwierć wieku XXI (por. Kurek 2019a; Kurek 2020). Osobno rozpatruję tzw. feminatywa odmężowskie, oddzielnie zaś formacje odojcowskie, czyli gwarowe określenia synów i córek. Analizowany zbiór antroponimów obejmuje 
niespełna 400 nazw własnych kobiet zamężnych i 220 patronimicznych form oznaczających synów i córki. Aby lepiej zobrazować proces zanikania formantów rodzinnych, nazwy kobiet zamężnych analizuję w grupach obejmujących cztery pokolenia żon, a formacje odojcowskie - w trzech grupach wiekowych synów i córek.

W gwarach Dukielszczyzny zarówno nazwy żon, jak i określenia odojcowskie w zdecydowanej większości tworzone są od: 1) nazwiska męża/ojca, 2) imienia męża/ ojca, 3) przezwiska męża/ojca.

Zanikanie formantów rodzinnych w nazwach kobiet zamężnych

W pokoleniu respondentek urodzonych na Dukielszczyźnie na przełomie XIX i XX wieku do tworzenia nazw kobiet zamężnych używano przyrostków: -ino, -ka oraz -owo. Najbardziej produktywnym formantem (ok. 57\% zebranych antroponimów) był wówczas sufiks -ka, por. Baranka < Baran, Boczarka < Boczar, Czarniczka < Czarnik, Głódka < Głód, Korzeńka < Korzeń, Kroczka < Krok, Maciejka < Maciej, Moskalka < Moskal, Wielgoska < Wielgos, Zajączka < Zając. Mniej produktywny był przyrostek -owo (ok. 30\% formacji odmężowskich), por. Kumciowo < Kumcio, Pawłowo < Paweł, Psiakościowo < Psiakość, Szczurkowo < Szczurek, Szymonowo < Szymon, Wawrzkowo $<$ Wawrzek, a tylko ok. 3\% nazw żon utworzono wtedy za pomocą formantu -ino, por. Jakielino < Jakieła, Nabaglino < Nabagło, Rachwalino $<$ Rachwat 1 .

Przyrostka -ino nie używano już jednak do tworzenia nazw kobiet zamężnych urodzonych w latach trzydziestych i na początku czterdziestych XX wieku. W tej grupie pokoleniowej dominował sufiks -owo wyżej społecznie wartościowany w marytonimicznym systemie polszczyzny ogólnopolskiej. W zebranym materiale pojawił się on w ok. 53\% odmężowskich feminatywów, por. Adasiowo $<$ Adaś, Brajowo $<$ Braja, Drozdowo < Drozd, Kordysiowo < Kordyś, Noszczykowo < Noszczyk, Pacowo < Pac, Wolkowiczowo < Wotkowicz, obok nieco mniej licznego formantu -ka (ok. 44\% nazw żon), por. Cyranka < Cyran, Drajewiczka < Drajewicz, Durałka $<$ Durat, Matusiczka $<$ Matusik, Nawratowiczka < Nawratowicz. Przyrostek -owo zanotowałam też w wariancie z tzw. - a jasnym, por. Belczykowa, Kleinowa.

W pokoleniu żon urodzonych pod koniec lat pięćdziesiątych i w latach sześćdziesiątych XX wieku wyraźnie widać stopniowe zanikanie obu sufiksów tworzących formacje odmężowskie. Nadal dominuje przyrostek -owo/-owa (ok. 37\% zebranych w tej grupie antroponimów), por. Knajzlowo $<$ Knajzel, Piotrkowa $<$ Piotrek, Stasiakowo < Stasiak, Szepielakowo < Szepielak, ale typowy dla gwar formant -ka tworzy już tylko ok. 20\% określeń żon, por. Draganka < Dragan, Liska < Lis, Penarka < Penar.

Do nazywania mężatek urodzonych w dziewięćdziesiątych latach XX wieku oraz na początku wieku XXI nie używa się już formantów rodzinnych. W badanych wsiach ta grupa kobiet identyfikowana jest za pomocą: 1) przypisanych im w młodości określeń odojcowskich, czyli - struktur składniowych, a zwłaszcza związków z przyimkiem

${ }^{1}$ Od męskich nazwisk o charakterze przymiotnikowym formy żeńskie tworzono odpowiednio: Jasiński > Jasińsko, Przybytkowski > Przybytkowsko, Biały > Biało, Gniady > Gniado. W materiale zanotowałam też przyrostki ruskiego pochodzenia, por. Chłapcia $<$ Chłap. 
i dopełniaczem typu: imię + od + gen. $s g$. nazwiska/imienia/przezwiska ojca lub matki, por. Hanka od Durała, Gośka od Kogutki lub 2) imienia (często w formie zdrobniałej) i nazwiska, por. Jolka Krowicko/Krowicka, Aneta Szczurek.

Zanikanie formantów rodzinnych w nazwach synów

Do tworzenia nazw synów urodzonych na Dukielszczyźnie w dwudziestych i trzydziestych latach XX wieku sporadycznie już wykorzystywano tzw. formanty rodzinne, aczkolwiek pojawiały się jeszcze trzy przyrostki: 1) -ik/-yk - Staszek Chłapik, 2) -ów Mietek Seredów oraz 3) -in/-yn - Staszek Chłapcin, Jasiek Karolczyn, Staszek Milczyn, Tadek Karolczyn, Zbyszek Boczarczyn, Zdziszek Karolczyn. Powszechnie stosowano natomiast formacje z przyimkiem i dopełniaczem typu: imię $+o d+$ gen. sg. nazwiska/ imienia/przezwiska ojca lub matki, por. Edek od Jantka, Fredek od Boczarki, Mundek od Józka, Tosiek od Głoda.

Za pomocą sufiksów -ik/-yk oraz -ów nie identyfikowano już jednak synów urodzonych w latach pięćdziesiątych i sześćdziesiątych XX wieku, a przyrostek -in/-yn, por. Wacek Marysin, Wojtek Janczyn, pojawiał stosunkowo rzadko. Powszechnie używano natomiast struktur składniowych typu: Józek od Barana, Leszek od Mundka, Manek od Wielgosa, Wojtek od Bolka.

Tego typu formacje notowałam również w najmłodszym pokoleniu synów, ale na początku XXI wieku w omawianej grupie wiekowej zaczęły dominować identyfikatory w postaci imienia i nazwiska, por. Michat Wielgos, Sławek Knajzel.

\section{Zanikanie formantów rodzinnych w nazwach córek}

We wsiach poddukielskich do identyfikacji córek urodzonych w dwudziestych i trzydziestych latach XX wieku rzadko używano tzw. formantów rodzinnych. W zebranym materiale zanotowałam tylko dwa sufiksy: -ina/-yna, por. Dziunia Chłapcina, Talusia Marysina, Janka Milczyna oraz -owa, por. Mańcia Baranowa, Władzia Szczurkowa, Marysia Wielgosowa. Powszechne były natomiast struktury typu: Jagniszka od Barana, Cesia od Psiakościa, Władka od Kumcia.

W pokoleniu córek urodzonych w pięćdziesiątych i sześćdziesiątych latach XX wieku sporadycznie pojawiał się jeszcze sufiks -owa, por. Basia Szepielakowa, Lucyna Bolkowa, ale zdecydowanie dominowały już struktury składniowe typu: imię + od + gen. sg. nazwiska/imienia/przezwiska ojca lub matki, por. Hania od Durała, Jadzia od Kobieli, Jaśka od Stasiaka, Tereska od Pawłowy.

W XXI wieku na Dukielszczyźnie nie tworzy się już nazw córek za pomocą formantów słowotwórczych. Ciągle produktywne są natomiast struktury typu: Marynia od Kozubala, Weronika od Drozda, Zosia od Gniadego. 


\section{Nazwy żon, synów i córek w substandardzie wiejskim a nietypowe problemy badawcze współczesnej dialektologii}

W XXI wieku w substandardzie wiejskim Dukielszczyzny do nazywania żon nie używa się już tzw. formantów rodzinnych. Ich miejsce zajęły określenia córek nadane mężatkom w dzieciństwie. Córki i synów urodzonych w XXI wieku identyfikuje się podobnie, bo za pomocą struktur składniowych typu: imię $+o d+g e n$. sg. nazwiska/ imienia/przezwiska ojca lub matki (albo za pomocą imienia i nazwiska). $Z$ jednej strony stan ten jest $\mathrm{z}$ pewnością swoistą zmodyfikowaną kontynuacją gwarowego nazewnictwa żon, synów i córek (już bez formantów słowotwórczych), ale z drugiej - idealnie wpisuje się w proces upowszechniania się konstrukcji przyimkowych w polszczyźnie ogólnej.

Od przełomu wieków XX i XXI w języku ogólnopolskim nasila się proces nominatywizacji imion i nazwisk, a zmiany te nie omijają też substandardu wiejskiego. W bogatym materiale zebranym we wsiach poddukielskich notowałam bowiem struktury typu: Julka od Artura Drozd, Zosia od Michała Wielgos, Jasiek od Tomka Nabagło, Piotrek od Tomka Kolanko, Marysia od Artura Rzońca, Jagusia od Danki Kobiela, Patrycja od Anety Jakieta. W grupach nominalnych: imię + nazwisko rządzonych przez przyimek od drugi człon - nazwisko - pozostawiono w formie nieodmienionej, a to oznacza, że fleksyjne funkcje antroponimu jako całości przejęło imię. Ten model fleksji zakorzenił się już na Dukielszczyźnie w zapisanych intencjach mszy świętych, por. intencja od Danuty Rykała (Danuta Rykała), intencja od Wtadystawa Rykata (Władysław Rykała), od rodziny Szyszlak, od rodziny Kielar, od rodziny Ciuła. Lektura intencji mszalnych $\mathrm{z}$ regionu dukielskiego wyraźnie wskazuje też na kierunek ewolucji systemu fleksyjnego antroponimów na badanym terenie. Otóż w celu zachowania jednoznaczności strukturalnej imienia i nazwiska w zapisanych intencjach zaprzestano bowiem również odmieniania imion, por. módlmy się za Wladystaw Kobiela, za zmartego Eugeniusz Wierdak, za zmartego Lucjan Czaja, za zmartego Tadeusz Wottosz, za zmarta Beata Wojdyła, za zmarła Zdzistawa Ziębka. Stąd w substandardzie wiejskim już tylko krok do struktur: Julka od Artur Drozd, Zosia od Michat Wielgos, Jasiek od Tomek Nabaglo, Piotrek od Tomek Kolanko, Marysia od Artur Rzońca, Jagusia od Danka Kobiela, Patrycja od Aneta Jakieła, które szerzą się przecież w zapisanej (i mówionej) polszczyźnie ogólnopolskiej, por. Dyplom dla Gabryś Pawel, Sędzia komisarz postępowania upadtościowego prowadzonego wobec: Mikulski Stanistaw, Sędzia komisarz postępowania upadłościowego prowadzonego wobec KRZANAK Bogumita (Kurek 2019b, 57, 77).

W prognozowanych formacjach odmężowskich oraz w nazwach synów i córek typu: Julka od Artur Drozd, Zosia od Michat Wielgos, Jasiek od Tomek Nabagto, Patrycja od Aneta Jakieła, które nie dublują już dopełniaczowych funkcji pełnionych jednocześnie przez przyimek oraz przez końcówki fleksyjne imienia i nazwiska, rolę końcówki przypadka zależnego - dopełniacza przejmuje przyimek od, precyzyjnie wpisując się w system przypadkowy imion i nazwisk. Konsekwencją zastępowania dopełniacza neutralną formą mianownikową (Artura Drozda > Artur Drozd, Michała Wielgosa > Michat Wielgos, Tomka Nabagty > Tomek Nabagło, Anety Jakiety > Aneta Jakieła) będzie więc wzrost frekwencji konstrukcji przyimkowych w substandardzie 
wiejskim paralelnie do form występujących już często w zapisanej i mówionej polszczyźnie ogólnej, zwłaszcza w Internecie, por. odbierz wiadomość od Jarek Fazan, badania lekarskie dla pan Marian.

Badania substandardowej polszczyzny najmłodszego pokolenia mieszkańców wsi wymagają dziś zatem skupienia się zarówno na problemach wynikłych z zastępowania systemów dialektalnych przez bardziej prestiżowy język ogólnopolski, jak i z przejmowania przez substandard wiejski tych samych wzorców ewolucyjnych, jakie obserwujemy w zapisanym i mówionym języku ogólnym. Nominatywizacja imion i nazwisk prowadząca do uproszczenia systemu przypadkowego polszczyzny, która, moim zdaniem, jest początkiem głębokich i gruntownych zmian w systemie fleksyjnym języka polskiego, dotknie bowiem również substandard wiejski, a w tym funkcjonujące w gwarach struktury składniowe służące do nazywania żon, synów i córek.

Współczesna dialektologia - pisał Jerzy Sierociuk - musi [więc - uzup. H.K.] poszukiwać nowych rozwiązań metodologicznych. Język mieszkańców współczesnej wsi zmienia się [bowiem - uzup. H.K.] na naszych oczach; jednocześnie zmiany te dokonują się w sposób bardziej złożony, niż by to wynikało z obserwacji pojedynczych idiolektów (Sierociuk 2012, 233).

\section{Literatura}

Handke K. (2008), Socjologia języka, Warszawa.

Karaś M. (2017), O gwarowych formantach onomastycznych, [w:] M. Karaś, Ze studiów leksykologicznych i onomastycznych, Kraków, s. 155-163.

Kosyl C. (1993), Nazwy osobowe, [w:] Encyklopedia kultury polskiej XX wieku, t. 2: Współczesny język polski, red. J. Bartmiński, Wrocław, s. 423-437.

Kurek H. (2018), Kultura ludowa przełomu wieków XX i XXI. Tradycja i zmiana, „Słowo. Studia językoznawcze", nr 9, s. 84-91.

Kurek H. (2019a), Obraz społeczności wiejskiej Dukielszczyzny zakrzepty w nazwach kobiet zamężnych. Tradycja i zmiana, Studia Dialektologiczne V, red. B. Grabka, R. Kucharzyk, A. Tyrpa, Kraków, s. 203-213.

Kurek H. (2019b), Przemiany fleksji nominalnej w polszczyźnie przełomu wieków XX i XXI (na przykładzie imion i nazwisk oraz appellativów), Kraków.

Kurek H. (2020), Obraz społeczności wiejskiej zakrzeply w nazwach synów i córek. Tradycja $i$ zmiana (na przykładzie wsi poddukielskich $w$ Beskidzie Niskim), „LingVaria”, XV, nr 2 (30), s. 121-132.

Markowski A. (2005), Kultura języka polskiego. Teoria. Zagadnienia leksykalne, Warszawa.

Miodunka W. (2003), Moc języka i jej znaczenie w kontaktach językowych i kulturowych, [w:] Współczesna polszczyzna. Wybór opracowań, t. 2: Warianty języka, red. J. Bartmiński, J. Szadura, Lublin, s. 12-16.

Ożóg K. (2007), Konteksty kulturowe współczesnej polskiej wsi, [w:] Gwary dziś, t. 4. Konteksty dialektologii, red. J. Sierociuk, Poznań, s. 213-220.

Sierociuk J. (2012), Dialektologia wobec językowo-kulturowych przeobrażeń współczesnej wsi, [w:] Gwary dziś, t. 6. Aktualne problemy dialektologii słowiańskiej, red. J. Sierociuk, Poznań, s. 219-234. 